\title{
Influence of some social and environmental factors on the nutrient intake and nutritional status of schoolchildren
}

\author{
ANN JACOBY, D. G. ALTMAN, JUDITH COOK, AND W. W. HOLLAND \\ Department of Community Medicine, St. Thomas's Hospital Medical School, London \\ A. ELLIOTT \\ Formerly a member of Kent County Council
}

\begin{abstract}
Jacoby, A., Altman, D. G., Cook, J., Holland, W. W., and Elliott, A. (1975). British Journal of Preventive and Social Medicine, 29, 116-120. Influence of some social and environmental factors on the nutrient intake and nutritional status of schoolchildren. Only children had significantly higher intakes of many nutrients and nutrients $/ 1000 \mathrm{kcal}$ than other children. A higher proportion of only children was found to be obese. There were no significant differences according to birthrank in intakes by children.

There were more obese children among the fatherless than those with fathers, in particular among those whose mothers were widowed. However, this was not accounted for by the present dietary findings, since fatherless children had lower intakes of carbohydrate and added sugar.

There were no differences in nutrient intake or intake/1000 kcal by mother's country of origin or her level of education, or by disposable income.
\end{abstract}

Differences in attained height and weight between different social groups have often been demonstrated, and have generally been attributed to environmental conditions, including differences in nutrition. However, detailed dietary data have been collected in very few studies, and the exact nature of nutritional differences is therefore unclear. In a recent study in Sweden (Samuelson, Grahnén, and Arvidsson, 1971) the authors collected dietary, social, and anthropometric data for a group of schoolchildren. They found that children from families of lower socioeconomic status had higher intakes of cakes and confectionery, and a lower intake of fruit.

In the present study detailed dietary, social, and anthropometric data were collected for a group of schoolchildren, and it has thus been possible to investigate the relationship of socio-economic factors to both nutrient intake and nutritional status.

The influence of social class, number of siblings, and mother's work status has already been discussed (Cook et al., 1973). These three variables were not generally associated with highly significant differences in average daily nutrient intake. Children of lower social class and from larger families had significantly higher intakes of carbohydrate. Children from the higher social classes had higher intakes of allō nutrients $/ 1000 \mathrm{kcal}$ except carbohydrate and sugar, $\stackrel{2}{\Rightarrow}$ and those from smaller families had higher intakes of all nutrients $/ 1000 \mathrm{kcal}$ except carbohydrate. This was taken to indicate that these groups had af better quality of diet. Whether or not the child's mother worked had little influence on nutrient intake. . $^{\circ}$

In this paper the influence of some other socioeconomic variables on both the nutrient intake and 3 nutritional status of the children are examined and discussed.

The STUdY

The study was carried out in Kent from September $\frac{}{2}$ 1968 to March 1970 . The study method has already been described in detail (Topp, Cook, and Elliott, $\sim$ 1972). For each child in the study, information $N$ collected comprised a one-week weighed diet record, a socio-economic questionnaire*, and a medical ${ }^{\omega}$ examination. Children who failed to record their food intakes adequately were included in the refusale group.

Altogether 778 children $(76.5 \%)$ aged between? 8 and 11 years and 13 and 15 years, satisfactorily

- Copies of the questionnaire can be obtained from the authors 
completed the study. All but 46 of these children agreed to take part in the medical examination at which anthropometric measurements were taken and children were examined for signs of possible vitamin deficiency. Each child was also assessed clinically, by one of two doctors, as being obese or of good, fair, or poor nutritional status. None of the children was considered to be of poor nutritional status. The findings of the medical examination will be discussed in detail in a later paper.

Detailed social data were collected using a questionnaire administered in the home by trained field-workers.

\section{FAMILY STRUCtURE}

\section{RESULTS}

There was a highly significant association between the children's assessed nutritional status and the number of siblings they had (Table I). The proportion of obese children was highest among those with no siblings, while most of the children assessed as being of fair nutritional status were from families of five or more children.

TABLE I

ASSESSED NUTRITIONAL STATUS BY NUMBER OF SIBLINGS

\begin{tabular}{c|ccc|c}
\hline \multirow{2}{*}{ No. of Siblings } & \multicolumn{4}{|c}{ Nutritional Status } \\
\cline { 2 - 5 } & Obese & Good & Fair & Totals \\
\hline \multirow{3}{*}{0} & 20 & 80 & 3 & 103 \\
& $(19 \cdot 4 \%)$ & $(77 \cdot 7 \%)$ & $(2 \cdot 9 \%)$ & $(100 \%)$ \\
& 18 & 114 & 2 & 134 \\
2,3 & $(13 \cdot 4 \%)$ & $(85 \cdot 1 \%)$ & $(1 \cdot 5 \%)$ & $(100 \%)$ \\
& 19 & 207 & 6 & 232 \\
& $(8 \cdot 2 \%)$ & $(89 \cdot 2 \%)$ & $(2 \cdot 6 \%)$ & $(100 \%)$ \\
& 23 & 218 & 22 & 263 \\
\hline Totals & 80 & 619 & 33 & 732 \\
\hline
\end{tabular}

$\chi^{2}=25.4 ; P<0.001$

N.B. 46 children who refused the medical examination are excluded

Since more of the only children were assessed to be obese, their intakes were compared with those of children with siblings using multiple covariance analysis. The covariates in the analysis were age, sex, and social class. Only children had higher mean daily intakes of all nutrients except carbohydrate and added sugars (Table IIA). The differences were statistically highly significant for intake of animal protein, vitamin $\mathrm{A}$, riboflavin, vitamin $\mathrm{C}$, and pyridoxine. Only children also had highly significantly greater intakes of most nutrients/1000 kcal (Table IIB).
The amount of food children eat may be influenced not only by the number of siblings they have to compete with, but also their position within the family. For this reason, the children's intakes (and intakes $/ 1000 \mathrm{kcal}$ ) were examined according to their birth rank in the same way as previously. Only children were excluded from this analysis. Except for mean daily intake and intake/1000 kcal of calcium there were no statistically significant differences according to birth rank (Tables IIIA and IIIB).

\section{FATHERLess ChildRen}

It was felt that fatherless children might be particularly 'at risk' with regard to nutrition. Investigation of the incomes of the fatherless families showed that their mean total weekly income was $£ 19 \cdot 90$, while families with fathers had a mean total weekly income of $£ 28 \cdot 40$. More mothers in the fatherless group worked, with relatively more employed full-time (Table IV). There was no

\section{TABLE IV}

MOTHER'S WORK STATUS ACCORDING TO WHETHER OR NOT CHILDREN ARE FATHERLESS

\begin{tabular}{l|cccc}
\hline \multirow{4}{*}{ Children } & \multicolumn{3}{|c|}{ Mother's Work Status } \\
\cline { 2 - 5 } & $\begin{array}{c}\text { Not } \\
\text { Working }\end{array}$ & Part-time & Full-time & Totals \\
\hline \multirow{4}{*}{ Without fathers } & 24 & 28 & 17 & $\begin{array}{c}69 \\
(34 \cdot 8 \%)\end{array}$ \\
Others & $(40 \cdot 6 \%)$ & $(24 \cdot 6 \%)$ & $(100 \%)$ \\
& 329 & 262 & 118 & 709 \\
Totals & $(46 \cdot 4 \%)$ & $(37 \cdot 0 \%)$ & $(16 \cdot 6 \%)$ & $(100 \%)$ \\
\hline & 353 & 290 & 135 & 778 \\
\hline
\end{tabular}

$\chi^{2}=7.93 ; P<0.01$

statistically significant difference in family size between fatherless families and the rest.

In spite of any apparent monetary disadvantage, it has previously been shown that the fatherless children had a better quality of diet, for although they had lower average daily intake of energy and nutrients they had a higher intake of all nutrients/ $1000 \mathrm{kcal}$ except for carbohydrate and added sugars (Cook et al., 1973).

A higher proportion of fatherless children, in particular those whose mothers were widowed, were found to be obese (Table V).

\section{FAMILY INCOME}

Since food consumption may be influenced by the amount of money available an attempt was made to ascertain the level of the household's disposable 

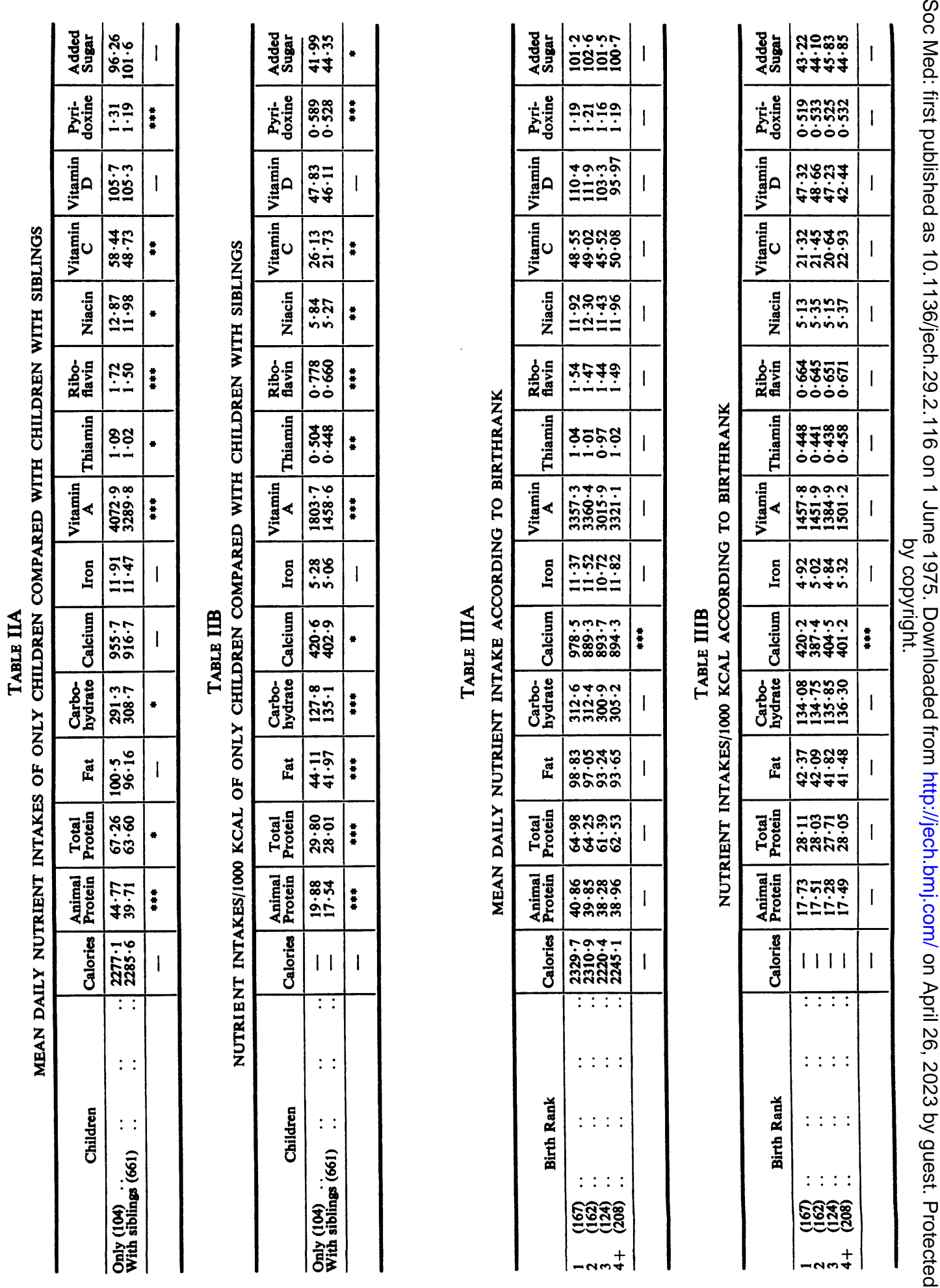
TABLE V

NUTRITIONAL STATUS ACCORDING TO MOTHER'S MARITAL STATUS

\begin{tabular}{|c|c|c|c|c|c|}
\hline \multirow{2}{*}{\multicolumn{3}{|c|}{ Marital Status }} & \multicolumn{3}{|c|}{ Nutritional Status } \\
\hline & & & \multirow{2}{*}{$\begin{array}{l}\text { Obese } \\
62 \\
(9.3 \%)\end{array}$} & \multirow{2}{*}{ 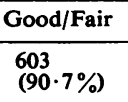 } & \multirow{2}{*}{$\begin{array}{c}\text { Totals } \\
\begin{array}{c}665 \\
(100 \%)\end{array}\end{array}$} \\
\hline Married & . & .. & & & \\
\hline Widowed & . & .. & $\stackrel{12}{(34 \cdot 3 \%)}$ & $\begin{array}{l}23 \\
(65 \cdot 7 \%)\end{array}$ & $\begin{array}{l}35 \\
(100 \%)\end{array}$ \\
\hline $\begin{array}{l}\text { Divorced, } \\
\text { unmarried }\end{array}$ & $\begin{array}{c}\text { parated, } \\
.\end{array}$ & .. & $\begin{array}{l}6 \\
(18 \cdot 8 \%)\end{array}$ & $\stackrel{26}{(81 \cdot 3 \%)}$ & $\begin{array}{l}32 \\
(100 \%)\end{array}$ \\
\hline Totals & .. & $\ldots$ & 80 & 652 & 732 \\
\hline
\end{tabular}

$x^{2}=23.4 ; P<0.001$

N.B. 46 children who refused the medical examination are excluded.

income. Five different measures of income were obtained:

husband's gross income;

husband's net income;

total family income;

total income less the cost of housing;

per capita income.

Regression analysis was carried out to determine whether any relationship existed between nutrient intake and income. For almost all the nutrients and nutrients $/ 1000 \mathrm{kcal}$ by each income measure, the regression was not significant, and the amount of variation in nutrient intake accounted for by income was very small (about $1 \%$ ).

\section{Mother's Education ANd COUNTRY OF ORIGIN}

There were no statistically significant differences in the average daily nutrient intakes or intakes/ $1000 \mathrm{kcal}$ of the children according to the age at which their mothers had completed their education. Similarly, there were no differences according to the country of origin of their mothers. In addition there was no difference in the assessed nutritional status of the children by either of these variables.

\section{Discussion}

It has previously been shown that the number of siblings influences mean daily intake and intake/ $1000 \mathrm{kcal}$ (Cook et al., 1973). A child's food intake may depend not only on the number of siblings with whom he must share the available food, but also the position within the family. However, birth order seemed to have little influence on intake, other than for calcium. Douglas and Simpson (1964) showed that at age 7 , and again at ages 11 and 15 , children without siblings were fatter than the others. Grant (1964) found that first-born children with siblings did not achieve the heights and weights of those first-born children who remained only children. She suggested that this was related to food consumption, and the results of the present study support this, since consumption of nutrients of only children was significantly higher than that of other children, with the exception that their diet was relatively less rich in carbohydrate and sugar. This may be because only children were more likely to be obese, and many of the obese children were on diets, and restricted their intakes of carbohydrate and sugar.

It has been found that a higher proportion of fatherless children than others took school meals and received them free. Those who took them also obtained a higher proportion of their weekday intakes of nutrients from school meals (Cook et al., 1975). At the time of the study, individuals receiving supplementary benefit (with the exception of widows, for whom the earnings rule had been removed), were allowed to earn only up to $£ 2$ before loss of benefits was incurred, and it was found that the average total weekly income of mothers living alone fell considerably below that of families with fathers. It may be that mothers living alone regard school meals as an important contributor to their children's diets, and being in a position of acute financial constraint depend upon them to a considerable extent.

A higher proportion of fatherless children was found to be obese, particularly the children of widowed mothers, and this could not be accounted for by family size or present dietary findings, since these children had lower intakes of carbohydrate and added sugars. It could be that the differences in nutritional status developed at an earlier period in life, before the children became fatherless. There is evidence that childhood obesity may be related to feeding patterns in the first year of life (Shukla et al., 1972; Asher, 1966), but our data did not allow any detailed analysis of the relationship of anthropometric findings to earlier dietary habits. There may also be a bias in that children have fat fathers, who experience higher mortality, and this is supported by the finding that children whose fathers had died were most likely to be obese.

Previous studies have shown that income is not a good predictor of nutrient intake. In one study (Babcock, Church, and Gates, 1955), the nutritional intake of low, medium, and high income groups was compared, and the percentage of subjects having low intakes of one or more vitamins was found to be similar $(28 \%, 23 \%$, and $27 \%$, respectively). The report by the Ministry of Agriculture, Fisheries and Food, Household Food Consumption and Expenditure: 1970 and 1971, reviewed trends in food consumption for the five-year period 1966 to 1970 . It concludes that in this period, family size has been a more important determinant of nutrient intake than has 
the income of the head of the household. A survey in the USA (Massachusetts Department of Public Health, 1972) showed little relation between poverty and the intake of calories and protein, and concluded that family income was not related to adequacy of nutrition.

In the present study, the amount of variation in nutrient intake which could be explained by income was very small. Both social class and family size had more influence than income on the nutrient intakes of the children, and social class particularly influenced the quality of diet.

It seems that social class reflects a whole series of attitudes towards, and knowledge about, nutrition which are far more important than the amount of income in the household available to be spent on food. This suggests the importance of education in nutrition to ensure that money available is used to provide an adequate and well-balanced diet.

This work has been supported in part by a grant from the Department of Health and Social Security. Special thanks are due to the former health and education service staff of Kent County Council particularly the health visitors, district nurses, and midwives who carried out the field survey work; Mrs A. Melton and Mrs B. Winstanley who supervised the diet recording and completion of the socio-economic questionnaires; $\mathrm{Dr}$ W. T. C. Berry, Mrs M. Disselduff, and Dr S. J. Darke at the Department of Health and Social Security for their advice and guidance; Dr S. J. Darke for carrying out a proportion of the medical examinations; and Marti Parker for her help with the analysis. The data were analysed using the University of London CDC 7600 . Lastly we wish to thank the families and children who worked so hard on the diet recording.

Requests for reprints: Mrs Ann Jacoby, BA, Office of Population Censuses and Surveys, Room 405, St Catherine's House, Kingsway, London WC2.

\section{REFERENCES}

AsHer, P. (1966). Fat babies and fat children. The prognosis of obesity in the very young. Arch. Dis. ? Childh., 41, 672.

BabCOCK, M. J., ChURCh, H. N., and Gates, L. O. (1955). Nutritional status of industrial workers. II. Effects of $\bar{C}$ education, age, income and ethnic group. Milbank mem. Fd. Quart., 33, 137.

Cook, J., Altman, D. G., Moore, D. M. C., Topp, S. G., $\stackrel{\mathbb{\nabla}}{\unrhd}$ Holland, W. W., and Elliott, A. (1973). A survey of the nutritional status of schoolchildren: relationship between nutrient intake and socio-economic factors. Brit. J. prev. soc. Med., 27, 91.

,-- , JaCoBy, A., Holland, W. W., and Elliott, A. (1975). School meals and the nutrition of school- $\overparen{D}$ children. Brit. J. prev. soc. Med., 29, (in press).

Douglas, J. W. B. and Simpson, H. R. (1964). Height in relation to puberty, family size and social class: a i longitudinal study. Milbank mem. Fd. Quart., 42, $\overrightarrow{\vec{D}}$ no. $3,20$.

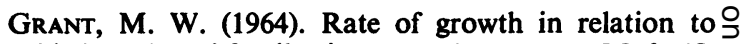
birth rank and family size. Brit. J. prev. soc. Med., 18, 35.

Massachusetts Dept. of Public Health (1972). Undernutrition in Massachusetts. New Engl. J. Med., 2, 886. $\vec{\varphi}$

Ministry OF AGRICUlture, Fisheries AND FOOD (1979. जे Household Food Consumption and Expenditure: 197 and 1971. A report of the National Food Survej Committee. HMSO, London.

Samuelson, G., Grahnén, H., and Arvidsson, E. (1971). A epidemiological study of child health and nutrition $\frac{0}{D}$ in a northern Swedish county. VI. Relationship between general and oral health, food habits and socio-economic $\vec{F}$ conditions. Amer. J. clin. Nutr., 24, 1361.

Shukla, A., Forsyth, H. A., Anderson, C. M., and MARWAH, S. M. (1972). Infantile overnutrition in the first year of life: a field study in Dudley, Worcestershire. Brit. med. J., 4, 507.

TopP, S. G., CooK, J., and Elliort, A. (1972). Measurement of nutritional intake among schoolchildren: aspects of methodology. Brit.J. prev. soc. Med., 26, 106. 